\title{
A EDUCAÇÃO DA INFÂNCIA DAS CLASSES POPULARES: UMA RELEITURA DAS OBRAS DE PAULO FREIRE'
}

\author{
Franciele Clara Peloso* \\ Ercília Maria Angeli Teixeira de Paula**
}

RESUMO: Paulo Freire foi um dos educadores brasileiros mais reconhecidos mundialmente. Todavia, é possível perceber que seus pressupostos são, na grande maioria, difundidos nos estudos e práticas sobre educação de pessoas jovens e adultas. Assim, o objetivo deste estudo foi o de apresentar outra leitura relativa aos pressupostos freirianos, ou seja, associá-los à educação da Infância. Pois, historicamente, o legado freiriano foi pouco mencionado nas práticas pedagógicas e discussões referentes a esse âmbito. A metodologia utilizada baseou-se numa pesquisa qualitativa, de caráter teórico. A partir da análise de oito das obras de Paulo Freire, considerou-se que: Freire fazia menção, em muitas passagens dessas obras, sobre diferentes infâncias, crianças e sua educação. Sob essa perspectiva, evidenciou-se que o pensamento freiriano pode se configurar como um forte aliado à compreensão da infância e da educação das crianças das classes populares. Palavras-chave: Paulo Freire. Educação da Infância. Infância das Classes Populares.

\section{EARLY-YEARS EDUCATION OF THE POORER CLASSES: \\ A RE-READING OF THE WORKS OF PAULO FREIRE}

ABSTRACT: Paulo Freire was one of the most well-known Brazilian Educators with worldwide recognition. However, it is possible to perceive that his assumptions are, for the most part, spread within studies and practices concerning the education of teenagers and young adults. Therefore, the aim of this study was to present an article relating to these "Freirian" presuppositions or, another words, finding an association between them and early years education. After all, historically, the "Freirian" legacy has been little mentioned in the pedagogical practices and discussions referring to this field. The methodology used was of a theoretical nature and based on a piece of qualitative research. Starting from an analysis of eight of Paulo Friere's works, it was considered how he made mention, in many passages, different experiences of early childhood, of children and their education. From this perspective, it became evident that "Freirian" thinking can become a strong ally in the understanding of early childhood and of the education of children from the poorer classes.

Keywords: Paulo Freire. Childhood. Early-years Education. Lower Classes.

\footnotetext{
* Graduada em Pedagogia pela Universidade Estadual do Centro-Oeste (UNICENTRO) e Mestre em Educação pela Universidade Estadual de Ponta Grossa (UEPG). E-mail: fr_clara@yahoo.com.br

** Mestre em Educação pela Universidade de São Paulo (USP); Doutora em Educação pela Universidade Federal da Bahia (UFBA); Professora adjunto 1 da Universidade Federal do Espírito Santo (UFES). E-mail: ercíliapaula@terra.com.br
} 


\section{INTRODUCุÃO}

A obra de Paulo Freire é extensa e contempla muitos aspectos e problemáticas referentes à educação. Com efeito, é perceptível, mesmo nas mais diferentes temáticas abordadas pelas obras desse educador brasileiro, conhecido mundialmente, que a sua preocupação principal esteve voltada para as questões referentes à Pedagogia da Libertação. No entanto, é possível perceber que seus pressupostos são, na grande maioria, difundidos nos estudos que trazem discussões sobre a educação de pessoas jovens e adultas.

Assim, com o objetivo de apresentar outra leitura relativa aos pressupostos freirianos, este trabalho traz aproximações do pensamento de Paulo Freire com a infância e as crianças das classes populares.

Sob essa perspectiva, foram realizadas análises de oito obras de Paulo Freire com o intuito apresentar outra leitura relativa aos pressupostos freirianos, ou seja, associá-los à educação da infância. Mesmo que Paulo Freire não tenha abordado especificamente, em suas obras, esse tema, é possível afirmar que seu pensamento de cunho político-pedagógico se apresenta como pensamento crítico, o que pode propiciar outro entendimento em relação à educação da infância das classes populares. Dessa maneira, buscou-se traçar, neste texto, algumas reflexões pouco reveladas dessa teoria e associá-las às infâncias e às crianças.

Para tanto, inicialmente, foram efetuadas algumas considerações sobre a metodologia que orientou tal investigação. Na sequência, foram abordadas algumas questões concernentes aos pressupostos do educador Paulo Freire. Em seguida, foram apresentados aspectos considerados relevantes sobre as obras analisadas, no sentido de indicar a incidência de alguns pensamentos de Paulo Freire relativos aos contextos da infância e sobre as crianças. E, por fim, nas conclusões deste artigo, foram destacados alguns elementos que permitem a reflexão da viabilidade de se recriar os pressupostos freirianos no referido âmbito educacional.

\section{ASPECTOS METODOLÓGICOS}

Este estudo compõe parte de uma dissertação de mestrado, cujo objetivo foi o de investigar a teoria de Paulo Freire e refletir sobre a via- 
bilidade de se recriar os pressupostos dessa teoria nos contextos referentes à educação da infância. Para tanto, esta pesquisa caracterizou-se como qualitativa (RICHARDSON, 1999) e de caráter teórico-empírico (TRIVIÑOS, 2007).

Os procedimentos metodológicos utilizados se pautaram na análise das obras de Paulo Freire, mais precisamente as obras solo e publicadas em português, no período de 1991 a 2000: A educação na cidade (1991); Pedagogia da esperança: um reencontro com a Pedagogia do oprimido (1992); Política e educação (1993); Professora sim, tia não: cartas a quem ousa ensinar (1993); Cartas a Cristina: reflexões sobre minha vida e minha práxis (1994); À sombra desta mangueira (1995); Pedagogia da Autonomia: saberes necessários à prática educativa (1996) e Pedagogia da indignação: cartas pedagógicas e outros escritos (2000).

A opção por essas obras ocorreu pelo fato de que considerou-se que, nesse período, Freire apresentou maior homogeneidade no estilo de suas obras e expressou o amadurecimento de sua linguagem como educador político.

Observou-se que Paulo Freire, em todas as obras selecionadas, em vários momentos, mencionou a palavra criança a diversos contextos da infância, geralmente de classes populares.

Com efeito, a relevância deste estudo está em contribuir para a releitura do legado de Paulo Freire, no sentido de que se façam possíveis outras interpretações de sua obra e, também, para a área dos estudos sobre infâncias e crianças, pois, ao verificar a aproximação do pensamento de Freire com estudos dessa área, é possível oferecer uma contribuição ao debate sobre esse campo de conhecimento.

\section{PAULO FREIRE:}

\section{$O$ EDUCADOR DE MUITAS FACES}

A escolha por Paulo Freire justifica-se uma vez que esse educador tratava das concepções de homem, de mundo, de realidade, de sociedade, de educação de forma humanizada. Sob essa perspectiva, Paulo Freire acreditava que a vocação ontológica das pessoas era a busca do ser mais. Para tanto, essa era uma busca constante: a do processo da humanização. Essa busca implica um novo projeto de sociedade. É a humanização da espécie humana, como um todo, que deve ser concretizada na 
superação das contradições presentes nas realidades sociais que oprimem e atrofiam a capacidade de o humano ser corpo consciente em um mundo histórico e socialmente constituído.

Para Freire, a vida humana só tem sentido na busca incessante pela libertação de tudo aquilo que desumaniza e proíbe o ser mais. De acordo com Zitkoski (2006), percebe-se, na teoria freiriana, o esforço para reelaborar várias questões já abordadas pela tradição filosófica ocidental, colocando-as sob uma nova ótica e recriando, assim, os modos de conceber e fundamentar a racionalidade humana em seu processo histórico de produção de sentido, para a existência das pessoas diante da humanização do mundo.

Segundo Zitkoski (2006, p. 69-70):

Freire situa-se na passagem do paradigma filosófico da modernidade - que se ancorava na subjetividade humana enquanto medida de todas as coisas e produção de todo e qualquer sentido possível - para um novo paradigma fundamentado na relação sujeito-sujeito (relação intersubjetiva), que requer a prática da solidariedade, da comunicação e do dialogo; fundamentados na vida em sociedade e da produção de todo e qualquer sentido humanamente válido. Nesses termos, o educador supera a modernidade, embora seja "moderno" em certos aspectos de sua proposta teórica, principalmente em sua defesa incondicional da utopia e da esperança como molas propulsoras da história humana. A originalidade de Freire está na superação da modernidade ao buscar construir, crítica e criativamente, novos elementos para conceber a vida humana em sociedade de modo radicalmente democrático e libertador. Ele é também original ao elaborar uma nova visão epistemológica, considerando a produção do conhecimento de forma dialógica, intersubjetiva e dialeticamente aberta para o dinamismo da vida, para a diferença e para o inédito, além de inspirar profundas inovações na visão política e ética dos problemas que desafiam o mundo atual.

Paulo Freire ficou conhecido como filósofo e teórico da educação pelo mundo todo. Sua marca registrada era não separar a teoria da prática. Outra marca registrada era o seu jeito simples e bem-humorado. Seu corpo era frágil e suas palavras eram fortes! Nas andarilhagens que fez pelo mundo, era muito observador. Suas observações eram críticas e, ao mesmo tempo, poéticas. Ao ler seus livros, às vezes tem-se a impressão que ele tinha um olhar de criança detalhista que observava o universo nos fenômenos e gestos mais simples, que eram descritos de forma sensível e crítica. 
Nesse entender, Freire (2001a, p. 101) testemunhou que:

Eu acho que uma das coisas melhores que eu tenho feito na minha vida, melhor do que os livros que eu escrevi, foi não deixar morrer o menino que eu não pude ser e o menino que eu fui, em mim. [...] sexagenário, tenho sete anos; sexagenário, eu tenho quinze anos; sexagenário, amo a onda do mar, adoro ver a neve caindo, parece até alienação. Algum companheiro meu de esquerda já estará dizendo: Paulo está irremediavelmente perdido. E eu diria a meu hipotético companheiro de esquerda: Eu estou achado: precisamente porque me perco olhando a neve cair. Sexagenário, eu tenho 25 anos. Sexagenário, eu amo novamente e começo a criar uma vida de novo.

As obras de Paulo Freire revelaram que ele tinha muita delicadeza e era sutil para descrever as relações de poder e desumanização. Ele parecia sempre ver o outro lado das coisas. Por isso, ousou sustentar que o oprimido era sujeito da transformação de sua realidade, isso quando consciente de sua capacidade de agir e refletir sobre si e sobre o seu estar no mundo. Com efeito, reconheceu que a educação é essencialmente ato de conhecimento e de conscientização e que, por si só, não leva uma sociedade a se libertar da opressão; mas também acreditou que a educação podia melhorar a condição humana, pois ele a entendia como parte de uma totalidade política e social e que podia contribuir para o que considerava ser a "vocação ontológica da espécie humana": a humanização.

Paulo Freire defendeu que todo ser humano aprende com a própria vida e pode compreender a existência a partir de si mesmo. Outrossim, a vida e a obra de Paulo Freire são pensamentos compartilhados. Seu rememorar esteve como pano de fundo para a compreensão de sua essência. Uma das evidências desse movimento de viver, construir e reconstruir sua trajetória era o modo como o próprio Freire misturava-se à sua narrativa. Pode-se dizer que o trabalho e a obra de Paulo Freire constituíram-se a partir de uma espécie de percurso de idas e vindas de sua vida.

De maneira geral, pode-se dizer que a pedagogia de Paulo Freire consistia em dialogar com as massas sobre a sua ação-reflexão-ação sobre e na realidade sócio-histórica. Era e é a pedagogia das pessoas, empenhando-se na luta por sua libertação. Perante tal conceito, essa pedagogia apresentou basicamente dois momentos distintos: um primeiro em que os oprimidos descobriam-se oprimidos e desvelavam o mundo da opressão, comprometendo-se com a práxis, em transformar a sua condição de opri- 
midos; e um segundo, que passaria por sua ação, transformar a realidade opressora. Freire denominou esses dois momentos de conscientização libertadora.

Nessa perspectiva, Freire também discutiu sobre a concepção bancária da educação e por que ela se caracterizava como um instrumento de opressão. Ele a contrapunha à concepção problematizadora da educação, que foi referenciada em sua teoria como instrumento de libertação das pessoas.

Em suma, Freire tinha fé na capacidade das pessoas, no sentido de recriar as relações sociais, o mundo e, com isso, estabelecer uma sociedade mais justa e fraterna. Por pensar assim, foi chamado por muitos de utópico e justificou tal consideração dizendo que somente a utopia é capaz de protagonizar mudanças (FREIRE, 1992). Nesse sentido, este trabalho optou por estudar e tentar compreender a educação da infância, em especial aquela das classes populares, a partir das ideias desse educador, pela complexidade que apresentam.

É importante sinalizar que Paulo Freire não elaborou nenhuma concepção teórica sobre as infâncias e crianças e, portanto, não dialogou, em sua obra, com autores colocando-se no interior desse debate. Assim, o que se apresenta aqui, como já mencionado, é a tentativa de apresentar uma releitura dos pressupostos presentes nas obras de Freire. Contudo, é possível afirmar que as ideias de Freire (2005) voltadas para uma educação libertadora podem ser aproximadas à educação da infância, em especial aquela das classes populares. Isso porque as crianças das classes populares, quando destituídas de garantias fundamentais, como educação, habitação, saúde, lazer, cultura, entre outros aspectos, encontram-se como pessoas "oprimidas" em sua forma de ser e estar no mundo. O fato de elas terem suas garantias limitadas as impede de apresentar uma postura autônoma frente ao contexto social no qual estão inseridas.

Com efeito, no próximo tópico, serão apresentadas as obras selecionadas para este estudo, individualmente, de acordo com a cronologia de sua publicação. Nesse sentido, alguns fragmentos foram descritos para melhor demonstrar como Paulo Freire citou as crianças em suas obras e, em que perspectiva, buscou-se associar seus pressupostos para/na educação da infância. 


\section{PENSANDO SOBRE A INFÂNCIA E AS CRIANÇAS ENCONTRADAS NAS OBRAS DE PAULO FREIRE}

A obra A Educaşão na Cidade ([1991] 2006a) é composta por entrevistas proferidas por Freire no período de 1989 a 1991. Essa obra foi construída quando Paulo Freire foi secretário municipal da educação, no estado de São Paulo, na administração de Luiza Erundina.

Observa-se que os textos dessa obra abordam principalmente as questões relacionadas ao acesso, à permanência, à participação e à qualidade da educação ofertada às crianças das classes populares. Freire também mencionou sua preocupação com o tipo de avaliação oferecida para essas crianças.

Para Freire, os momentos da avaliação, da aferição do saber, se constituem como um dos elementos mais importantes da prática educativa. Reflexionava ele: "Os critérios de avaliação do saber dos meninos e meninas que a escola usa, intelectuais, formais, livrescos, necessariamente ajudam as crianças das classes sociais chamadas favorecidas, enquanto desajudam os meninos e as meninas populares" (FREIRE, [1991] 2006a, p. 22).

Frente ao exposto, o que Freire buscava salientar era que a avaliação na escola não considerava o "saber de experiência feito". As experiências trazidas pelas crianças não eram consideradas, suas vidas, suas lutas, suas histórias, entre outros aspectos e, com isso, as crianças das classes populares saiam em desvantagem, pois sua cotidianidade era muito distante da "exigida" pela escola.

Mais uma evidência de que Freire pensou sobre a educação da infância, bem como se sentiu curioso diante da possibilidade de realizar um trabalho com crianças, apareceu na página 23, quando ele comentou sobre a experiência que teve no Chile com um grupo de camponeses "semeadores de palavras". Diante dessa experiência, Freire ([1991] 2006a, p. 23) comentou que "gostaria de acompanhar uma população infantil envolvida num projeto assim e observar seus passos na experiência de alfabetização". Essa vontade manifestada por Freire demonstrou que as crianças não ficaram ausentes das suas reflexões, nem mesmo às suas curiosidades relativas à alfabetização.

Certamente, por sentir esse tipo de curiosidade, Freire, durante sua gestão na prefeitura de São Paulo, também não esqueceu as escolas de 
educação infantil: "Tenho falado muito, desde antes mesmo de assumir a Secretaria de Educação Municipal, no nosso sério empenho de mudar a cara de nossa escola, incluindo as escolas de Educação Infantil” ([1991] 2006a, p. 33). É importante lembrar que Freire foi secretário da educação no período de 1989 a 1991 e, nesse período, as escolas de educação infantil ainda não eram reconhecidas como parte integrante e etapa inicial da educação básica, visto que tal reconhecimento só se deu em 1996, com a Lei n. 9394/96.

Freire acreditava que as escolas deveriam se transformar em centros de criatividade, em que ensinar e aprender fosse um momento alegre. Para ele, além de "mudar a cara da escola", era preciso demonstrar o respeito pelas crianças, suas professoras, sua escola, seus pais, sua comunidade e, para isso, era necessário ouvir as crianças, as sociedades de bairro, pais, mães, diretoras de escola, professoras, zeladores, merendeiras, comunidade científica, entre outros. O respeito a que Freire se referia era o de entender as crianças como parte ativa e constituinte da escola.

Em muitas passagens dessa obra, Freire ([1991] 2006a, p. 35) fez menção à evasão escolar:

Em primeiro lugar, eu gostaria de recusar o conceito de evasão. As crianças populares brasileiras não se evadem da escola, não a deixam porque querem. As crianças populares brasileira são expulsas da escola - não, obviamente, porque esta ou aquela professora, por uma questão de antipatia pessoal, expulse estes ou aqueles alunos ou os reprove. É a estrutura mesmo da sociedade que cria uma série de impasses e dificuldades, uns em solidariedade com os outros, de que resultam obstáculos enormes para as crianças populares não só chegarem à escola, mas também, quando chegam, nela ficarem e nela fazerem o percurso a que têm direito.

Pelo exposto, ficou explícita a concepção de escola que Freire propunha, ou seja, uma escola popular, que atendesse aos interesses das crianças populares. Que respeitasse o seu saber de experiência feito e que, a partir de um projeto político-pedagógico maior, diminuísse os índices de "expulsão" das crianças do povo.

Em vários momentos, Freire ressaltou que pensar na educação das crianças de classes populares não era fazer injustiça às crianças das classes favorecidas. Nas palavras de Freire ([1991] 2006a, p. 42), "é preciso deixar claro, porém, que a escola que queremos não pretende, de um lado, fazer injustiça às crianças das classes chamadas favorecidas, nem, de 
outro, em nome da defesa das populares, negar a elas o direito de conhecer, de estudar o que as outras estudam".

Nesse sentido, Freire defendeu que pensar numa escola para as crianças das classes populares exigia a reformulação do seu currículo para que a escola como um todo atendesse aos anseios dessas crianças. Uma escola na qual a criança popular tivesse condições de aprender, de criar, de arriscar, de perguntar, de crescer, entre outros aspectos.

Outra concepção evidenciada nessa obra mencionou o direito que as crianças das classes populares têm de estar atualizadas, ou seja, de ter conhecimento dos avanços da ciência. Conforme Freire ([1991] 2006a, p. 45), "para nós não há sombra de dúvida em torno do direito que as crianças populares têm de, em função de seus níveis de idade, a ser informadas e formar-se de acordo com o avanço da ciência".

Freire criticava as pedagogias que domesticavam as crianças e também as que não conseguiam atender seus objetivos porque exacerbavam a alegria, a afetividade, em detrimento da cognitividade, por isso afirmava:

[...] não é preciso endurecer o porte das crianças, não é preciso pôr colarinho e gravata na criança para que ela, imbuída de um certo sofrimento, que é o sofrimento do saber, possa aprender. Não. Mas, por outro lado, é preciso não afrouxar para que a criança não se perca apenas no brinquedo, apenas em alegria. Saber é um processo difícil realmente, mas é preciso que a criança perceba que, por ser difícil o próprio processo de estudar se torna bonito [...]. (FREIRE [1991] 2006a, p. 58).

Com efeito, percebe-se que Paulo Freire refletia sobre a educação das crianças e a necessidade da disciplina "ensinada" com amorosidade.

Já na obra Pedagogia da Esperança: um reencontro com a Pedagogia do Oprimido (1992), Freire explicitou alguns momentos que considerou fundantes para a construção de seus pressupostos teóricos. Os momentos a que Freire se referiu foram aqueles que oportunizaram encontros com as realidades mais diversas, as quais o permitiram dar partida às grandes questões colocadas em torno do projeto de educação que procurou defender ao longo dos tempos.

É perceptível, pela leitura atenta, com o olhar mais sensível às questões da infância, que esses momentos estavam intimamente ligados aos encontros estabelecidos por Freire com o universo infantil, quando 
rememorava alguns aspectos de sua vida e quando da sua atuação como diretor do setor de educação do Sesi.

Nessa obra, novamente, Freire (1992, p. 85-86) voltou a fazer menção à necessidade de considerar o "saber de experiência feito" e afirmou: "O que tenho dito sem cansar, e redito, é que não podemos deixar de lado, desprezado como algo imprestável, o que educandos, sejam crianças chegando a escola ou jovens e adultos a centros de educação popular trazem consigo de compreensão do mundo".

Em outro momento da obra, as crianças foram lembradas por Freire a partir de uma reflexão sobre as classes sociais. Ao afirmar que as classes sociais continuavam existindo e que o mundo tem o capitalismo por excelência, as crianças foram lembradas, por ele, em situações drásticas. Segundo Freire (1992, p. 95-96):

Que excelência é essa que registra nas estatísticas, mornamente os milhões de crianças que chegam ao mundo e não ficam e, quando ficam, partem cedo, ainda crianças e, se mais resistentes, conseguem permanecer, logo do mundo se despedem. (...) Que excelência é essa que, no Nordeste brasileiro, convive com uma exacerbação tal da miséria que parece mais ficção: meninos, meninos, mulheres, homens, disputando com cachorros famintos, tragicamente, animalescamente, detritos dos grandes aterros de lixo, na periferia das cidades, para comer. (...). Que excelência é essa que parece não ver meninos barrigudos, comidos de vermes (...) cinqüenta e dois por cento da população do Recife favelada, vítima fácil das intempéries, das doenças que abatem sem dificuldades os corpos enfraquecidos (...). Que excelência é essa que não se comove com o extermínio de meninas e meninos nos grandes centros urbanos brasileiros; que "proíbe" que 8 milhões de crianças populares se escolarizem, que "expulsa" das escolas grande parte das que conseguem entrar.

Ainda nessa obra, Freire descreveu um dos momentos em que a educação da infância esteve contextualizada em suas teorias pedagógicas. Ele relatou seu encontro com um grupo de trabalhadores espanhóis, imigrantes na Suíça, que queriam discutir com ele a constituição de uma escola de educação da infância a partir da Pedagogia do Oprimido, leitura que confirmava algumas intuições pedagógicas que moviam a concretização dessa experiência.

Os camponeses espanhóis encontraram nos pressupostos freirianos, presentes na Pedagogia do Oprimido, suporte para implementar ums escola na qual as crianças pudessem problematizar sua própria vida, por 
meio da experiência, de um pensar crítico em torno do mundo, que pudessem estudar com seriedade, aprender e criar uma disciplina de estudo. De acordo com Freire (1992, p. 141), o sonho dos espanhóis era o "de uma educação aberta, democrática, que estimulasse nas crianças o gosto da pergunta, a paixão do saber, da curiosidade, a alegria de criar e o prazer do risco sem o qual não há criação".

Nesse sentido, Freire analisou, juntamente com esse grupo de espanhóis, a possibilidade de uma escola para crianças na qual o maior objetivo seria diminuir o risco de alienação imposto às crianças pela escola suíça. Nessa experiência, certamente Freire concebia, entre outros aspectos, a viabilidade de concretização de suas ideias descritas na Pedagogia do Oprimido, também na educação da infância.

Ainda há outro relato de Freire presente nessa obra em que ele mencionou a utilização de seus pressupostos na educação da infância. Esse relato decorreu de sua visita ao Caribe, em 1979, para discutir, juntamente com os responsáveis pela educação daquele país, uma proposta educativa. Esses breves relatos apresentam elementos para a reflexão dos pressupostos freirianos em diferentes esferas educativas e, também, para desmistificar a ausência da utilização desses pressupostos na educação da infância.

Já na obra Política e Educação (1993), Freire discorreu sobre a reflexão político-pedagógica, com vistas a compartilhar com seus leitores uma compreensão crítica da história e da educação. Nessa obra também fez menção às crianças e aos contextos da infância.

Freire defendeu a educação como formação, como processo de conhecimento, de ensino, de aprendizagem, que se tornou, ao longo da história, a vocação para a humanização, ou seja, o homem sempre está inserido em uma prática educativa e é isso que o torna humano. No entanto, Freire afirmou que esta prática educativa não se dá em termos provisórios, mas em termos de vida inteira. Dizia ele: "o ser humano jamais pára de educar-se” ([1993] 2001b, p. 13). Subentende-se que o período da infância está aqui contextualizado.

Ao se reportar à educação popular, mais especificamente ao processo de conhecimento, Freire novamente lembrou a educação da infância e considerou as crianças como seres integrantes e ativos da sociedade: 
Respeitando os sonhos, as frustrações, as dúvidas, os medos, os desejos dos educandos, crianças, jovens ou adultos, os educadores e educadoras populares têm neles um ponto de partida para a sua ação. Insista-se, um ponto de partida e não de chegada. Crianças e adultos se envolvem em processos educativos de alfabetização com palavras pertencentes à sua experiência existencial, palavras grávidas de mundo. Palavras e temas. Assim compreendida e posta em prática, a Educação Popular pode ser socialmente percebida como facilitadora da compreensão cientifica que grupos e movimentos podem e devem ter acerca de suas experiências (FREIRE [1993] 2001b, p. 16).

Também, ao analisar a questão da necessidade da intervenção competente e democrática do educador nas situações dramáticas em que os grupos populares, "demitidos da vida", geralmente se encontram, Freire ([1993] 2001b) descreveu que não se podia recusar a importância do saber de experiência feito, da cotidianidade.

Ao retomar a discussão dos projetos idealizados e concretizados quando assumiu a Secretaria de São Paulo, novamente, discutiu suas inquietações relativas à educação das crianças, principalmente aquelas das classes populares. Freire ([1993] 2001b, p. 51) afirmou que:

Enquanto sofríamos um déficit escolar elevado a 60\% das unidades da rede escolar em estado precário o orçamento que recebemos previa cifras astronômicas para o que se chama grandes obras. Viadutos, túneis majestosos, ligando um bairro a outro, jardins, etc. não que os viadutos, os túneis, os jardins, os parques não sejam necessários. Não é da necessariedade que falo, mas da prioridade das necessidades. E é aí que se contradizem as opções. É que há prioridades para as classes dominantes e prioridades para as classes dominadas. Os viadutos eram prioritários, mas, para servir às classes abastadas e felizes, com repercussão adjetiva também entre as classes populares. As escolas eram prioritárias para as classes populares, com repercussão adverbial para as classes ricas. Do ponto de vista, contudo, do interesse imediato das classes populares, mais valia ter escolas equipadas e competentes para seus filhos do que viadutos escoando facilmente o tráfego dos carros poderosos. Saliente-se que não estamos negando aos ricos e felizes o direito de desfrutar o prazer de trafegar em seguros viadutos. Estamos defendendo apenas o direito de milhares de crianças estudarem como prioridade ao conforto de que já o tem excesso...

Nesse sentido, percebe-se, portanto, as preocupações de Freire com as desigualdades sociais e a condição de vida das crianças das classes populares e suas experiências vividas na infância e, também, que suas con- 
cepções de/para a educação da infância estavam atreladas ao seu projeto de educação popular.

Já a obra Professora sim, tia não: cartas a quem ousa ensinar (1993) foi organizada em dez cartas que trazem uma discussão sobre o comprometimento que exige "ser professora". Freire relatou que a intenção era mostrar que a tarefa do "ensinante", que é também aprendiz, é prazerosa e igualmente exigente. Assim, Freire abriu a discussão afirmando que ensinar é uma tarefa que exige trabalho e especificidade na execução. Ser tia, para ele, era uma relação de parentesco, portanto não se configurava como profissão. Nota-se que, com essas afirmações, Freire não tinha a intenção de desvalorizar a "tia" e, sim, de valorizar a professora, mostrando o que lhe é fundamental: a responsabilidade profissional que faz parte da exigência política de sua profissão e de sua formação de educadora.

Nesse sentido, observou-se que a obra toda, mesmo tendo como ideia central questões relativas à "professora", tinha como pano de fundo um projeto educativo, e nele estavam contextualizadas a infância e a criança.

Freire apontou, em muitas passagens dessa obra, que a atitude das professoras era fundamental para um bom andamento dos projetos educativos. Outrossim, defendia a ideia de que as professoras precisavam se libertar das práticas dos "pacotes", caso contrário não era possível que as crianças fossem livres, críticas e criadoras. Nesse entender, seguem alguns trechos que demonstram a inclusão das crianças na abordagem freiriana:

Se nossas escolas, desde a mais tenra idade de seus alunos se entregassem ao trabalho de estimular neles o gosto da leitura e o da escrita, gosto que continuasse a ser estimulado durante todo o tempo de sua escolaridade, haveria possivelmente um número bastante menor de pós-graduandos falando de sua insegurança ou de sua incapacidade de escrever (FREIRE [1993] 2008, p. 37).

A prática educativa, pelo contrário, é algo muito sério. Lidamos com gente, com crianças, adolescentes ou adultos. Participamos de sua formação. Ajudamo-los ou os prejudicamos nesta busca. Estamos intrinsecamente a eles ligados no seu processo de conhecimento. Podemos concorrer com nossa incompetência, má preparação, irresponsabilidade, para o seu fracasso. Mas podemos, também, com nossa responsabilidade, preparo científico e gosto do ensino, com nossa seriedade e testemunho de luta contra as injustiças, contribuir para que os educandos vão se tornando presenças marcantes no mundo (FREIRE [1993] 2008, p. 47). 
Nos excertos, transparece a presença das crianças e de sua infância como processo. Subentende-se que Freire concebia a criança como "alguém que é e está sendo", por isso, mesmo quando em suas obras ele não citava literalmente a palavra "criança" ou "infância", esse período da existência humana já está contextualizado em suas reflexões e análises que tematizam sobre um projeto amplo de bumanização (grifo nosso).

Ainda nessa mesma obra, Freire retomou a questão da tensão entre autoridade e liberdade e, mais uma vez, nessa discussão, estão contextualizadas as crianças no seu período da infância:

Retomo agora a análise do autoritarismo, não importa se dos pais e mães, se das professoras ou professores. Autoritarismo frente ao qual podemos esperar nos filhos e alunos ora posições rebeldes, refratárias a quaisquer limites, disciplina ou autoridade, mas também apatia, obediência exagerada, anuência sem crítica ou resistência ao discurso do autoritário, renúncia a si mesmo, medo à liberdade (FREIRE [1993] 2008, p. 56).

Ao dizer que do autoritarismo se pode esperar vários tipos de reação, entendo que, felizmente, no domínio do humano as coisas não se dão mecanicamente. Desta forma, é possível a certas crianças passar quase ilesas à rigorosidade do arbítrio, o que não nos autoriza a jogar com esta possibilidade e a não nos esforçar por ser menos autoritários se não por causa do sonho democrático, em nome do respeito do ser em formação de nossos filhos e filhas de nossos alunos e alunas (FREIRE [1993] 2008, p. 57).

Em alguns trechos, Freire ([1993] 2008, p. 98) insistia que as educadoras precisavam saber o que se passava no mundo das crianças com quem trabalham, "O universo de seus sonhos, a linguagem com que se defendem, manhosamente, da agressividade de seu mundo. O que sabem $e$ como sabem independentemente da escola". É perceptível, nessa preocupação, uma sensibilidade muito grande com o universo infantil, com o mundo afetivo das crianças. Freire se referia ao mundo trágico, dramático, em que vivia um sem-número de crianças. Para exemplificar, citou o seguinte exemplo:

"Você costuma sonhar?", perguntou certa vez um repórter de TV a uma criança de uns dez anos, bóia-fria, no interior de São Paulo. "Não", disse a criança espantada com a pergunta. "só tenho pesadelo." (...) O mundo afetivo desse sem-número de crianças é roto, quase esfarelado, vidraça estilhaçada. Por isso mesmo essas crianças precisam de professoras e de professores 
profissionalmente competentes e amorosos e não de puros tios e de tias (FREIRE [1993] 2008, p. 69).

E além de saber o que se passava no mundo das crianças, Freire defendia a necessidade de compreender o contexto em que elas viviam. Isso implicava respeitar a sintaxe, a ortografia, a semântica, a prosódia das crianças das classes populares.

Freire considerava que, a partir do momento em que as crianças fossem compreendidas, e também as relações com elas mesmas, com os outros e com o mundo, é que se tornariam protagonistas de mudanças. A esse respeito, Freire ([1993] 2008, p. 105) argumentava:

Não podemos deixar de levar em consideração as condições materiais desfavoráveis que muitos alunos de escolas da periferia da cidade experimentam. A precariedade de suas habitações, a deficiência de sua alimentação, a falta em seu cotidiano de atividades de leitura da palavra, de estudo escolar, a convivência com a violência, com a morte de que se tornam quase sempre íntimos. Tudo isso é, de modo geral, pouco levado em consideração não apenas pela escola básica, de primeiro grau, em que essas crianças estudam, mas também nas escolas de formação para o magistério. Tudo isso, porém, tem enorme papel na vida dos Carlos, das Marias, das Carmens. Tudo isso marca, inegavelmente, a maneira cultural de estar sendo dessas crianças.

Percebe-se aqui uma preocupação não somente com as crianças, mas também com as educadoras da infância.

Em relação a algumas práticas que acontecem na escola, foram observadas, novamente, a contextualização da infância e das crianças, em um olhar bastante sensível e atento de Freire ([1993] 2008, p. 76), por exemplo: "As crianças têm uma sensibilidade enorme para perceber que a professora faz exatamente o contrário do que diz (...)".

Uma estratégia que Freire sugeriu, para aprender e ensinar juntos, eram os registros dos fatos. Ele explicou que a prática de registrar possibilita observar, comparar, selecionar, estabelecer relações entre fatos e coisas. Essa seria uma experiência formadora, pois educadoras e educandos anotariam diariamente seus momentos desafiadores. Aqui também aparecem infância e criança contextualizadas. Freire ([1993] 2008, p. 83) afirmou: 
Estou convencido, aliás, de que tal experiência formadora poderia ser feita, com nível de exigência adequado à idade das crianças, entre aquelas que ainda não escrevem. Pedir-lhes que falassem de como estão sentindo o andamento de seus dias na escola lhes possibilitaria engajar-se numa prática de educação dos sentidos. Exigiria delas a atenção, a observação, a seleção de fatos. Com isso desenvolveríamos também a sua oralidade que, guardando em si a etapa seguinte, a da escrita, jamais dela se deve dicotomizar. A criança que, em condições pessoais normais, fala é aquela que escreve. Se não escreve, torna-se proibida de fazê-la e, só em casos excepcionais, impossibilitada.

Mais uma vez, Freire deixava transparecer sua sensibilidade em relação às crianças, bem como o entendimento sobre as condições de ensino e aprendizagem adequadas a essa faixa etária.

Outro fator interessante presente nessa obra era quando Freire fez alusão à inclusão das crianças na vida e nas discussões político-pedagógicas da escola, mostrando-lhes dados do mundo real e colocando-as a par das discussões sociais e políticas da sociedade, como os desfalques materiais e os danos éticos causados pelos governantes. Nesse sentido, Freire ([1993] 2008, p. 89) asseverou que: "É preciso mostrar as cifras às crianças, aos adolescentes e dizer-lhes com clareza e com firmeza que o fato de os responsáveis agirem assim, despudoradamente, não nos autoriza, na intimidade de nossa escola, a arrebentar as mesas, estragar o giz, desperdiçar a merenda, sujar as paredes".

Essa afirmativa conduz à reflexão sobre como Freire acreditava na criança como "alguém que é e está sendo" e, por isso, na sua capacidade de já na infância buscar "ser mais". Outra constatação foi a de que Freire não desconsiderava, em suas reflexões, o ser criança, no período da infância, mas o considerava como natureza e parte essencial da experiência humana. Esse aspecto ficou explicitado no seguinte fragmento:

Gostaria então que pensássemos no seguinte: mulheres e homens, quando criancinhas, começaram a falar não dizendo letras, e sim palavras que valem frases - quando o neném chora e diz "mamã", o neném estará querendo dizer: "Mamãe, tenho fome" ou "mamãe, estou molhado". Estas palavras com que os bebês começam a falar se chamam "frases mono-palábricas", isto é, frases de ou com uma só palavra. Pois bem, se é assim que todos nós começamos a falar, como, então, no momento de aprender a escrever e a ler, devemos começar através de decoração das letras? 
Ninguém rigorosamente ensina ninguém a falar. A gente aprende no mundo, na casa da gente, na sociedade, na rua, no bairro, na escola. A fala, a linguagem da gente, é uma aquisição. A gente adquire a fala socialmente. A fala vem muito antes da escrita, assim como uma certa "escrita" ou o anúncio dela vem muito antes do que a gente chama escrita. E assim como é preciso falar para falar, é preciso escrever para escrever. Ninguém escreve se não escreve, assim como ninguém aprende a andar se não andar.

Por isso mesmo, devemos estimular ao máximo as crianças para que falem e para que escrevam. É das garatujas, uma forma indiscutível de escrita, que devemos elogiar, que elas partem para a escrita a ser estimulada. Que escrevam, que contem suas estórias, que as inventem e reinventem os contos populares de seu contexto ([1993] 2008, p. 109).

Além de acreditar na infância como condição da existência humana e na criança como "alguém que é e está sendo", Freire deixou transparecer nessa obra, como já exposto, que, em seus pressupostos, infância e criança não estavam ausentes, pelo contrário, acompanhavam suas reflexões e preocupações.

Freire também teve seu olhar e suas reflexões muito voltados para as questões da infância. Observou-se também que, nessas obras, ele retomava, em vários momentos, semelhantes afirmações sobre os contextos relativos à infância e à criança.

A obra Cartas a Cristina: reflexões sobre minha vida e minha práxis (1994) foi dividida em duas partes. Na primeira, evidenciou-se que Freire remetia constantemente à sua infância, enfatizando o grande educador que foi e as origens de sua profissão nesse período de sua vida:

O gosto em mim da liberdade que me fez, desde a mais tenra infância, sonhar com a justiça, com a equidade, com a superação dos obstáculos à realização jamais absoluta, na história, do que viria a chamar a vocação humana para o ser mais, me engajou até hoje, à minha maneira, na luta pela libertação de mulheres e de homens. O gosto da liberdade gerando-se no amor à vida, no medo de perdê-la (FREIRE [1994] 2003, p. 207).

O fragmento deixa transparecer a importância que Freire atribuía especialmente à sua infância. Certamente, Freire considerava-a um momento fundante em dois aspectos: na busca do ser mais e também na construção de seus pressupostos teóricos. 
No decorrer dessa obra, Freire fez alguns apontamentos sobre a educação dos filhos. Nesse sentido, retomou a discussão dos limites entre a autoridade e a liberdade. Com efeito, é possível afirmar que Freire se preocupava com, além da educação das crianças nas instituições de ensino, a educação que recebiam em suas famílias. Esse fato estava diretamente associado a como Freire considerava a educação um projeto maior, um projeto de sociedade. Nesse entender, a infância e a criança estavam contextualizadas, em todos os contextos em que se inseriam.

Assim, Freire ([1994] 2003), ao afirmar que a vocação para o ser mais se achava condicionada pela realidade concreta do contexto, pela realidade histórica, econômica, social, político-cultural, entre outros aspectos, explicitava que era preciso propor situações concretas aos educando para que tivessem a oportunidade de se manifestar, objetivando a democracia e a aprendizagem. Nesse sentido, para ele, não importava a idade dos educandos, a cor da pele, o sexo a que pertenciam ou a compreensão que dele tinham, era preciso estimular a aprendizagem da democracia.

Observa-se que, nessa busca pela aprendizagem da democracia, Freire ressaltava que existiam vários aspectos que necessitavam ser política e pedagogicamente tratados. Nesse viés, enfatizou o direito de ser criança, o direito de brincar, não importando a idade:

A luta, no Brasil, pela democracia, passa por uma série de possíveis ângulos a ser política e pedagogicamente tratados - o da justiça, sem a qual, não há paz, o direitos humanos, o do direito à vida, que implica o de nascer, o de comer, o de dormir, o de ter saúde, o de vestir, o de chorar os mortos, o de estudar, o de trabalhar, o de ser crianças, o de crer ou não, o de viver cada um e cada uma a sua sexualidade como bem lhe aprouver, o de criticar, o de discordar do discurso oficial, o de ler a palavra, o de brincar não importa a idade que se tenha, o de ser eticamente inconformado do que ocorre no nível local, no regional, no nacional e no mundial (...) (FREIRE [1994] 2003, p. 203).

Diante de tal afirmação, é possível dizer que Freire reconhecia que muitas crianças não tinham o direito de ser crianças devido a uma série de fatores que impossibilitavam o seu estar no mundo como crianças em busca do seu ser mais. Fatores como a miséria, a pobreza, experiências drásticas, dramáticas e castradoras de sua curiosidade, a alienação imposta pelo consumismo, entre outros aspectos.

$\mathrm{Na}$ obra À sombra dessa mangueira (1995), Freire realizou uma reflexão política sobre as estruturas sociais e também comunicou profun- 
da comunhão com a natureza e suas lembranças de infância. Com efeito, discorreu, em alguns parárafos, sobre a importância de sua infância, na busca de evidenciar que esse período da vida é essencial e significa de fato o início da busca do ser mais. Seguem alguns fragmentos para melhor exemplificar:

Meu primeiro mundo foi o quintal de casa (...). Não foi por acaso a escolha do título deste livro, aparentemente desligado do texto. Ele me devolve a meu quintal cuja importância na minha vida sublinho (FREIRE, [1995] 2006b, p. 24).

Aquele quintal foi a minha imediata objetividade. Foi o meu primeiro não-eu geográfico, pois os meus não-eus pessoais foram meus pais, minha irmã, meus irmãos, minha avó, minhas tias e Dadá (...). Foi com esses não-eus que me constituí como eu. Eu fazedor de coisas, eu pensante, eu falante (FREIRE, [1995] 2006b, p. 24-25).

Com efeito, é possível afirmar que Freire percebia sua vida como uma totalidade e entendia a infância como experiência humana. Para ele, as pessoas são uma "inteireza", que fazem a história e ao mesmo tempo se fazem e refazem em ação dialógica com outras pessoas e com o mundo. Esse pensamento de Freire pressupõe que, na história das pessoas, o que ocorre é a superação de uma fase geracional por outra, o que não elimina a continuidade da história no interior da mudança. Isso no faz pensar que a infância pode ser compreendida, com base nos pressupostos freirianos, como experiência humana e, se compreendida assim, é também encharcada de importância histórica, pois já faz parte da relação das pessoas no mundo, como mundo e com as outras pessoas; é processo igualmente de humanização, movimento de aprender a reconhecer-se, a constituir e construir-se permanentemente. Logo, é possível afirmar que a infância institui, juntamente como ser criança, a base de um projeto de constituição da humanidade do ser humano.

Pelo exposto, assevera-se que a infância não representa somente uma etapa cronológica, uma etapa passageira do desenvolvimento, mas representa a condição da existência humana. Nesse sentido, numa perspectiva freiriana, as crianças podem ser entendidas como pessoas produtoras de cultura, pessoas em relação com o mundo, no mundo e com outras pessoas, desde sempre, pois são e estão sendo pessoas imersas na realidade histórica e por isso são seres da intervenção. 
Tal obra nos propõe ainda refletir sobre a insistência de Freire ao afirmar, na maioria de suas obras, que a história é possibilidade, e não determinação. Para tanto, ele retoma, nessa obra, que o mundo é movimento, por isso ele não é, está sendo. Nessa perspectiva, o papel das pessoas não é o da adaptação, mas o da ação na história. Não é o de ser objeto da história, mas seu sujeito igualmente. Assim, é possível afirmar que se o ser humano for compreendido, desde a infância, no seu ser criança, como sujeito histórico social, será capaz de constituir sua identidade pessoal de modo a se perceber uma pessoa no mundo, com o mundo e com as outras. Reconhecerá a história como possibilidade e será capaz de protagonizar mudanças.

Freire nos alerta, também, que, para reconhecer a história como possibilidade, é também necessário que nos compreendamos como pessoas inacabadas, como pessoas inconclusas, sempre. É no reconhecimento da inconclusão que se funda a educação como processo permanente. Freire insistiu que as pessoas se tornaram educáveis na medida em que se reconheceram inacabadas. Nesse viés, é possível afirmar que a inconclusão gerou a educabilidade e a possibilidade de que as pessoas se tornem conscientes e se insiram na constante busca do ser mais. Assim, não é possível que as pessoas abandonem a sua infância, pois ela é, historicamente, parte constituinte da sua humanidade e da sua busca do ser mais.

No entanto, isso nos sugere a seguinte reflexão: como as pessoas, principalmente as de classes populares, podem se tornam sujeitos da história, constituir sua identidade pessoal, se desde a mais tenra idade se veem "obrigadas" a se adaptar ao mundo, sem, muitas vezes, compreenderem-se no mundo, com o mundo e também com as outras pessoas?

Pelo exposto, os apontamentos feitos em relação a essa obra nos fazem refletir sobre a urgência de o futuro constituir-se como necessidade histórica, urgência que implica continuidade, esperança e possibilidade de cada pessoa ser corpo consciente no mundo, com o mundo e com as outras pessoas, independentemente de sua fase geracional. Afirmamos, igualmente, a urgência de que as crianças sejam reconhecidas em seus contextos de infância, ou seja, em seus contextos históricos, sociais e culturais, como pessoas da comunicação, da intercomunicação, que sejam compreendidas em suas formas de ser e estar no mundo, com o mundo e com as outras pessoas.

Na obra Pedagogia da Autonomia: saberes necessários à prática educativa (1996), Freire objetivou discutir a formação docente ao lado da reflexão 
sobre a prática educativo-progressista, em favor da autonomia do ser dos educandos. Para tanto, essa obra abordou questões sobre a responsabilidade ética no exercício da ação docente. Freire destacou que a eticidade era a condição necessária para a prática formadora, pois na ética estava expressa a natureza da prática educativa. Assim, em várias partes do texto, fez referência às crianças.

Um dos aspectos que chama a atenção nessa obra fazia menção à autonomia que Freire creditava às crianças. Em vários fragmentos do texto, o autor considerava as crianças capazes, autônomas, bem como as inseriu em suas afirmações relacionadas à prática educativa e à busca do ser mais de todos os seres humanos. Mais uma vez, pareceu entender a criança como "alguém que é e está sendo" e a infância, como condição para a existência humana. No caso dessa obra, um primeiro fragmento que nos chamou a atenção foi o seguinte:

Numa madrugada, há alguns meses, estávamos Nita e eu, cansados, na sala de embarque de um aeroporto do Norte do país, à espera da partida para São Paulo num desses vôos madrugadores que a sabedoria popular chama de "vôo coruja". Cansados e realmente arrependidos de não haver mudado o esquema de vôo. Uma criança em tenra idade, saltitante e alegre, nos fez, finalmente, ficar contentes, apesar da hora para nós inconveniente. Um avião chega. Curiosa a criança inclina a cabeça na busca de selecionar o som dos motores. Volta-se para a mãe e diz: “O avião ainda chegou”. Sem comentar, a mãe atesta: "O avião já chegou". Silêncio. A criança corre até o extremo da sala e volta. "O avião já chegou”, diz. O discurso da criança, que envolvia a sua posição curiosa em face do que ocorria, afirmava primeiro o conhecimento da ação de chegar do avião, segundo o conhecimento da temporalização da ação no advérbio já. $\mathrm{O}$ discurso da criança era conhecimento do ponto de vista do fato concreto: o avião chegou e era conhecimento do ponto de vista da criança que, entre outras coisas, fizera o domínio da circunstância adverbial de tempo, no já (FREIRE, 1996, p. 61-62).

A partir desse relato, fica subentendida a afirmação de que Freire considerava o período da infância como condição da existência humana. É na infância que o ser humano utiliza a sua curiosidade e se reconhece inconcluso e, por isso, caminha incessantemente em sua busca de ser mais. Nesse entender, é possível afirmar que se o ser humano, ainda criança, for estimulado a não perder a sua curiosidade, que é natureza humana, pode concretizar sua busca e, de fato, ser mais, pois se assumirá como ser inacabado - sempre - e vai entender a história como possibilidade. 
Ao se referir à prática educativa, Freire (1996), em vários momentos, fez menção às crianças. Os excertos que melhor explicitam essa afirmação são os seguintes:

Outro saber necessário à prática educativa, e que se funde na mesma raiz que acabo de discutir - a da inconclusão do ser que se sabe inconcluso -, é o que fala do respeito decido à autonomia do ser educando. Do educando criança, jovem ou adulto. Como educador, devo estar constantemente advertido com relação a este respeito que implica igualmente o que devo ter por mim mesmo (FREIRE, 1996, p. 65-66).

[...] Se trabalho com crianças, devo estar atento à difícil passagem ou caminhada da heteronomia para a autonomia, atento à responsabilidade de minha presença que tanto pode ser auxiliadora como pode virar perturbadora da busca inquieta dos educandos, se trabalho com jovens ou adultos, não menos atento devo estar com relação a que o meu trabalho possa significar com estimulo ou não à ruptura necessária com algo defeituosamente assentado e à espera de superação (...) (FREIRE, 1996, p. 78).

Em outro momento da obra, ao se referir à autonomia do ser dos educandos, Freire (1996) descreveu novamente a criança em cena no seu período de infância:

O que é preciso, fundamentalmente mesmo, é que o filho assuma eticamente, responsavelmente, sua decisão, fundante de sua autonomia. Ninguém é autônomo primeiro para depois decidir. A autonomia vai se constituindo na experiência de várias, inúmeras decisões, que vão sendo tomadas. Por que, por exemplo, não desafiar o filho, ainda criança, no sentido de participar da escolha da melhor hora para fazer seus deveres escolares? Porque o melhor tempo para esta tarefa é sempre o dos pais? Por que perder a oportunidade de ir sublinhando aos filhos o dever e o direito que eles tem, como gente, de ir forjando sua própria autonomia? Ninguém é sujeito da autonomia de ninguém. Por outro lado, ninguém amadurece de repente, aos 25 anos. A gente vai amadurecendo todo dia, ou não. A autonomia, enquanto amadurecimento todo dia, ou não. A autonomia, enquanto amadurecimento do ser para si, é processo, é vir a ser. Não ocorre em data marcada. É neste sentido que uma pedagogia da autonomia tem de estar centrada em experiências estimuladoras da decisão e da responsabilidade, vale dizer, em experiência respeitosa da liberdade (FREIRE, 1996, p. 120-121).

Sob essa perspectiva, Freire expôs, mais uma vez, seu entendimento de infância e de criança, ou seja, a infância entendida como condi- 
ção para a existência humana, pois era o princípio da busca do ser mais e, por isso, a criança era compreendida "como alguém que é está sendo".

Com efeito, é possível afirmar que a infância e as crianças não estavam ausentes dos pressupostos freirianos, ao contrário, estavam significadas, nominadas, como sujeitos de preocupação e reflexão em seus escritos.

No livro Pedagogia da Indignação: cartas pedagógicas e outros escritos (2000), logo no início, Freire comunicou um propósito que era escrever para pais, mães, filhos e filhas adolescentes, ou professores e professoras, algumas reflexões, a fim de ajudá-los em suas experiências. As cartas, em estilo leve, tinham como pano de fundo a tensão entre liberdade e autoridade e, nelas, mais uma vez e com maior ênfase, estavam contextualizadas infância e crianças.

Freire (2000) asseverou que somos seres transformadores e, por isso, é nessa condição de seres transformadores que está à possibilidade de adaptação que não esgota no ser humano o estar no mundo. É porque o ser humano pode transformar o mundo, que está com ele e com os outros. Nesse sentido, entendeu que algumas crianças não vivem as tensões entre a liberdade e a autoridade, mas, sim, vivem a licenciosidade que as impede de ter uma atitude autônoma, de entenderem-se como seres da transformação, no mundo, com o mundo e com os outros, ou o autoritarismo, que as castra da mesma maneira. Conforme Freire (2000):

A mim me dá pena e preocupação quando convivo com famílias que experimentam a "tirania da liberdade", em que as crianças podem tudo: gritam, riscam as paredes, ameaçam as visitas em face da autoridade complacente dos pais que se pensam, ainda, campeões da liberdade. Submetidas ao rigor sem limites da autoridade arbitrária as crianças experimentam fortes obstáculos ao aprendizado da decisão, da escolha, da ruptura. Como aprender a decidir proibidas de dizer a palavra, de indagar, de comparar. Como aprender democracia na licenciosidade em que, sem nenhum limite, a liberdade faz o que quer ou no autoritarismo em que, sem nenhum espaço, a liberdade jamais se exerce? (p. 34).

(...) me dá pena também e preocupação, igualmente, quando convivo com famílias que vivem a outra tirania, a da autoridade, em que as crianças caladas, cabisbaixas, "bem-comportadas", submissas nada podem (p. 36).

Nesse entender, Freire afirmava que a melhor maneira de se educar uma criança é deixá-la consciente dos limites entre a autoridade e a 
liberdade, de forma a exercitar a gestação de sua autonomia, de torná-las "seres para si", capacitadas para avaliar, comparar, escolher, decidir e, finalmente, intervir no mundo.

Contudo, Freire deixava claro que as liberdades se constituíam entregues a si mesmas. No entanto, era preciso trabalhar com a criança a questão da autonomia para que ela não se tornasse egoísta: “(...) é necessário que a criança aprenda que a sua autonomia só se autentica no acatamento à autonomia dos outros" (FREIRE, 2000, p. 59).

Nesse entender, Freire clarificava que era necessário estimular e possibilitar para a criança a capacidade de intervenção no mundo, tratando-a como "alguém que é e está sendo" no mundo, como mundo e com os outros.

Mais uma vez, ao discorrer sobre os projetos educativos, Freire (2000) não hesitou em contextualizar a infância e as crianças. É possível perceber essa contextualização nos excertos que seguem:

Que precisamos nós, os chamados educadores, saber para viabilizar até mesmos os nossos primeiros encontros com mulheres, homens e crianças cuja humanidade vem sendo negada e traída, cuja existência vem sendo esmagada? (FREIRE, 2000, p. 78).

É a partir deste saber fundamental: mudar é difícil mas é possivel, que vamos programar nossa ação político-pedagógica, não importa se o projeto com o qual nos comprometemos é de alfabetização de adultos ou se crianças (...) (FREIRE, 2000, p. 81).

É importante que o educando não importa se alfabetizando adulto à procura do comando gráfico de sua linguagem ou se criança deslumbrando-se com suas descobertas do mundo ou se adolescente pensando o próprio pensar, é fundamental que o educando experimente sempre situações em que termine por incorporar a seu saber constituindo-se o saber de que errar é momento do processo de conhecer (FREIRE, 2000, p. 100-101).

Pelo exposto, acredita-se que as ideias de Paulo Freire contribuem para a maior compreensão de aspectos relacionados à educação da infância, em especial das classes populares. Aspectos que dizem respeito a algumas categorias centrais da obra de Freire, como o diálogo, a liberdade, a subjetividade, a amorosidade, a eticidade, a cidadania, o lazer, a socialização, a leitura de mundo, a utopia, o oprimido, a autonomia, a humanidade, entre outros. Nesse sentido, acredita-se que o diálogo com o pensa- 
mento de Paulo Freire nos contextos referentes à infância e à criança, em especial das classes populares, pode ser realizado em vários aspectos.

Freire foi um dos precursores da educação voltada para as classes populares. Foi um profundo conhecedor da realidade brasileira e das desigualdades sociais. Fomentou várias discussões a respeito da libertação dos homens. Defendeu que a educação é direito de todos, é um processo de humanização; vocação dos seres humanos para ser mais. No entanto, ele considerava que essa vocação, que é a da humanização, é negada frente à injustiça, à exploração, à opressão e à violência dos opressores e afirmada no "anseio de liberdade, de justiça, de luta dos oprimidos, pela recuperação de sua humanidade roubada" (FREIRE, 2005, p. 32).

Kramer (2003, p. 21) explica que as crianças, na maioria das vezes, são concebidas como objetos, como abstração, e não se leva em consideração as diferentes classes sociais nas quais elas estão inseridas. Dessa maneira: "Tratar as crianças em abstrato, sem levar em conta as diferentes condições de vida, é dissimular a significação social da infância [...]”.

Assim, quando a infância é compreendida nessa concepção de negação, não é possível que se cumpra o que Freire (2005) mencionava sobre o processo de humanização como vocação dos homens. Visto que, na maioria das vezes: "Os oprimidos, como casos individuais, são patologia da sociedade sã, que precisa, por isto mesmo, ajustá-los a ela [...]" (FREIRE, 2005, p. 69).

Nesse sentido, a criança precisa ser concebida e compreendida como "alguém que é e está sendo". Compreender a criança como "alguém que é e está sendo" oportuniza afirmar, em uma postura freiriana, que as pessoas, quando compreendidas dentro do mundo e num processo histórico de mudança, entendem-se e sabem-se inconclusas (FREIRE, 1996).

\section{TECENDO ALGUMAS CONSIDERACְÕES}

Este artigo objetivou apresentar outra leitura relativa aos pressupostos freirianos. Para tanto, foram apresentados fragmentos de oito das obras de Paulo Freire, nos quais ele retratou as crianças e as infâncias, principalmente aquelas de classes populares. Tais fragmentos procuraram evidenciar considerações da pedagogia desse educador para a educação da infância. 
Com efeito, a análise das obras deixou transparecer que Paulo Freire tinha preocupações com as crianças. Assim, seus pressupostos teóricos se apresentavam de maneira bastante significativa, para inspirar uma experiência pedagógica para/na educação da infância. Isso porque as crianças têm o direito de se apresentar como sujeitos do processo ensino e aprendizagem e do seu desenvolvimento humano e social.

Nessa perspectiva, está associado o entendimento que Freire tinha do ser humano na sua busca do ser mais. Freire entendia o ser humano como inconcluso, inacabado e, por isso, acreditava na sua capacidade de agir com autonomia diante do mundo, de esperançar, de querer conhecer, de ser mais. Esses aspectos estão associados à questão de que os seres humanos estão no mundo, com o mundo e com os outros, ou seja, o ser humano se faz inconcluso à medida que reconhece sua historicidade, que está associada aos condicionantes sociais e culturais.

Dessa maneira é possível afirmar que o projeto educativo proposto por Freire é anunciador do ser humano plural. Nesse sentido, seus pressupostos podem ser utilizados em diversos contextos educativos, principalmente naqueles em que os mecanismos de opressão, de exclusão, de preconceito, de subordinação, de miséria, entre outros, se fazem presentes e impedem a vocação de ser mais dos seres humanos: a humanização.

Outrossim, os pressupostos freirianos podem ser recriados na educação da infância, no que diz respeito à constituição de um espaço educativo dinâmico e desmistificador das realidades sociais. Observa-se que Freire se preocupou com a educação de todas as crianças, mas enfatizou a necessidade de maior atenção às crianças das classes populares, por fazerem parte de contextos que não respeitam a sua cultura. Dessa forma, considerou-se que o pensamento de Paulo Freire é um campo teórico fecundo para uma experiência pedagógica com as infâncias e as crianças. Essa experiência teria suas bases nas experiências vividas pelas crianças e suas infâncias, incluindo aí os aspectos histórico-culturais, o processo de construção do conhecimento e o desenvolvimento humano e social.

Em todas as obras analisadas por este estudo, Freire demonstrou sua preocupação com a educação da infância, principalmente com as infâncias e as crianças das classes populares, por serem desconsideradas em seu saber de experiência feito. Mais que isso, asseverou que a vida está intrinsecamente conectada ao inacabamento. Essa concepção de Freire 
nos permitiu afirmar que o ser humano, por se inconcluso, é um ser de desejo, que anseia por liberdade, é aberto às experiências no mundo, com o mundo e com os outros, por isso é sujeito político e social. Um ser que se faz histórico por assumir sua vocação ontológica na medida em que age no mundo para transformá-lo. Nesse sentido, a infância é condição para a existência humana. É na infância, no ser criança, que esse desejo se move.

Com efeito, se a infância for entendida como experiência humana e o ser criança, que já é ser humano, for entendido como sujeito histórico e social no mundo, com o mundo e com os outros desde sempre, é possível que se cumpra outro entendimento sobre todos os seres humanos, de modo que realizem, de acordo com Freire, sua vocação ontológica do ser mais: a humanização.

É importante salientar que Freire (2006b, p. 16) considerou que a primeira condição para que um ser possa assumir um ato comprometido está em ser capaz de agir e refletir, ou seja, é preciso que, estando no mundo, seja capaz de saber-se nele. Se a capacidade de agir e refletir sobre si e sobre o estar no mundo não faz parte da ação do ser humano sobre o mundo, ele não é capaz de transpor os limites que lhe são impostos pelo próprio mundo, passa a ser adaptado e não é capaz de compromisso, torna-se a-histórico, vive em um tempo que não é seu, passa a ser determinado pela história. Somente um ser que é capaz de se distanciar do seu contexto, que é capaz de admirá-lo para, objetivando-o, transformá-lo e, transformando-o, saber-se transformado, um ser que é e está sendo, em um tempo que é seu, que se faz determinante da história, é capaz, por tudo isso, de comprometer-se. Nessa perspectiva acredita-se que esse processo pode ter seu início ainda na infância, na educação infantil, se a criança for compreendida como um sujeito que necessita de auxílio para realizar algumas tarefas, mas que está presente no mundo e, por isso, precisa ser compreendida como "alguém que é e está sendo", é capaz de agir sobre ele e transformá-lo.

Sob essa perspectiva, a afirmativa de que os pressupostos freirianos podem ser recriados nos contextos relativos à educação da infância passa, então, pelo anúncio de outras possibilidades em relação às práticas realizadas com as crianças e também da maneira como é entendida a própria infância. Um aspecto que pode ser ressaltado faz menção ao entendimento do mundo proposto por Freire, ou seja, ele entendia o mundo 
como espaço de relações, em que os diferentes sujeitos educativos, por meio da ação dialógica, se vão constituindo como sujeitos de autonomia e de autoria da sua própria história.

As crianças podem ser assumidas como sujeitos de direitos, da fala, da escuta, do conhecimento, quando compreendidas a partir do exercício do diálogo e da capacidade de esperançar. Assim, vamos considerando que a recriação dos pressupostos freirianos relativos à educação da infância poderia supor sua constituição como processo de integração de culturas e emancipação de todos os seres humanos. Emancipação no sentido de que desde a infância o sujeito criança reconhecerá a história como possibilidade e por isso se constituirá como capaz de agir no mundo e transformá-lo. Nesse sentido, Freire deixou transparecer em suas obras, nas quais a concepção de ser humano e a sua busca do ser mais constituem elementos de base de um processo educativo sustentado pela ação dialógica, pela apreciação dos contextos sócio-históricos e pela valorização dos saberes, de experiências feito das crianças e ainda, pelo compromisso com a transformação das realidades. Uma prática que emancipa, que dá voz e sugere a autonomia das crianças para que sejam autoras de sua história e signifiquem o seu estar no mundo.

A rigor, tem-se conhecimento da existência de muitos trabalhos que abordam os pressupostos de Paulo Freire em distintas áreas e temáticas. No entanto, o intuito deste estudo esteve voltado para buscar compreender as reflexões de Paulo Freire na educação e apresentar outra leitura relativa aos pressupostos freirianos, ou seja, pensar sobre suas preocupações com as infâncias e as crianças. Entende-se que o pensamento freiriano propicia outro entendimento em relação à infância, à criança e a sua educação. Sob essa perspectiva, buscou-se analisar, portanto, o recriar do pensamento desse estudioso nos contextos associados à educação da infância. É importante salientar que esta pesquisa abre possibilidades de novas investigações. 


\section{REFERÊNCIAS}

FREIRE, P. À sombra desta mangueira. 8 ed. São Paulo: Olho d'Água, 2006b.

FREIRE, P. Cartas a Cristina: reflexões sobre minha vida e minha práxis. 2 ed. São Paulo: Unesp, 2003.

FREIRE, P. Educação na cidade. 7 ed. São Paulo: Olho d'Água, 2006a.

FREIRE, P. Pedagogia da Autonomia: Saberes necessários à prática educativa. 21 ed. Rio de Janeiro: Paz e Terra, 1996.

FREIRE, P. Pedagogia da esperança: um reencontro com a pedagogia do oprimido. Rio de Janeiro: Paz e Terra, 1992.

FREIRE, P. Pedagogia da Indignação. São Paulo: Editora Unesp, 2000.

FREIRE, P. Pedagogia do Oprimido. 40 ed. Rio de Janeiro: Paz e Terra, 2005.

FREIRE, P. Pedagogia dos sonhos possiveis. São Paulo: Unesp, 2001a.

FREIRE, P. Politica e Educação. 5 ed. São Paulo: Cortez, 2001b.

FREIRE, P. Professora sim, tia não. 19 ed. São Paulo: Cortez, 2008.

KRAMER, S; LEITE, M. I (Org). Infância: Fios e desafios da pesquisa. 7 ed. São Paulo: Papirus, 2003.

ZITKOSKI, J. J. Paulo Freire e Educação. Belo Horizonte: Autêntica, 2006.

RICHARDSON, R. J. et al. Pesquisa social: métodos e técnicas. 3 ed.São Paulo: Atlas, 1999.

TRIVIÑ̃OS, A. N. S. Introdução à pesquisa em Ciências Sociais: a pesquisa qualitativa em Educação. São Paulo: Atlas, 2006. 


\section{NOTAS}

1 Pesquisa financiada pela Capes.

2 Observa-se que se indicou a data da primeira publicação de cada obra entre colchetes e, na sequência, a data da edição utilizada para este estudo. Esse procedimento objetivou possibilitar que, no momento da leitura, seja possível remeter ao contexto de produção da obra.

Recebido: 07/07/2010

Aprovado: 04/07/2011

Contato:

Rua Osvaldo Aranha, 754

Centro

CEP 85504-360

Pato Branco, Paraná

Brasil 